\title{
Wrongfulness of a court's decisions, acts and/or omissions as a condition of tortious obligations in Ukraine
}

One of the general conditions determining the obligation to provide compensation for damage is the wrongfulness of the conduct of the person who caused such damage. There is no legal definition of unlawfulness in the civil legislation acts. However, the issue of wrongfulness in civil law is not new for legal science. Definitions of wrongfulness have been provided both by researchers who specialize in the general problems of responsibility in law ${ }^{1}$ and by experts in the field of civil liability. ${ }^{2}$ But almost all researchers have stated that different kinds of legal responsibility have their own specific features, and that the criteria of unlawfulness in criminal law cannot be completely applicable to civil relations. Generally, it can be noted that there are several key concepts (theories) concerning the definition of wrongfulness (wrongful conduct) as the condition for the compensation of damage in the doctrine of civil law: objective (normative) ${ }^{3}$ and objective-subjective. ${ }^{4}$ At the same time, wrongfulness has a special character and content in the process of evaluating the infliction of damage caused by public (including judicial) authorities.

1 Р.О. Халфина, Общее учение о правоотношении [General theory of legal relationship], Москва 1974, p. 324; Б.Т. Базылев, Юридическая ответственность (теоретические вопроcb) [Legal liability (theoretical issues)]. Красноярск 1985, р. 25; К.В. Басін, Юридична відповідальність: природа, форми реалізаиії та права людини [Legal liability: the nature, forms of implementation and human rights], Київ 2006, p. 10.

2 V., for example: В.Л. Слесарев, Объект и результат гражданского правонарушения [The object and the result of a civil offence]: Свердловск 1974, p. 24; С.А. Коновалов, Основание гражданско-правовой ответственности [The ground of civil liability], Москва 2006, p. 28.

3 И.С. Канзафарова, Гражданско-правовая ответственность (основные положения) [Civil liability (the main provisions)], Одесса 1998, p. 16.

4 А.М. Савицька, Поняття протиправності та ї̈ форми за радянським иивільним правом [The concept of wrongfulness and its forms under the Soviet civil law], Львів 1974, p. 6. 
In this context, the purposes of this research are: to identify the specificities of wrongfulness as a condition of the obligations determining the compensation of damage caused by the judicial authorities, namely the unlawfulness of their decisions, acts and/or omissions, and to make proposals on how to improve the legislation of Ukraine which governs this scope of legal relations.

The object of this analysis is the wrongfulness (unlawfulness) of a court's decisions, acts and/or omissions as a condition for tortious obligations.

The methodological basis of this analysis is presented by formal-logical, systemic, structural-functional and comparative methods, and by the method of analysis and synthesis.

The main body of research. First of all, it should be noted that we agree with the position of Olesia O. Otradnova ${ }^{5}$ on a broad understanding of wrongfulness in tort relationships: any act that results in a violation of a person's rights, harming their property or moral interests, if the person was not entitled to harm-doing, is unlawful.

It is necessary to pay attention to the position of those experts ${ }^{6}$ who believe that unlawfulness in the harm caused by public authorities has a special character and specific content: there is a "double" complex wrongfulness in such relations that has both civil and administrative (criminal procedural) components. That is, when deciding on the issue of the state's tort liability for harm caused by the exercise of power, the civil wrongfulness of such harm will be expressed in the public illegality of the powerful act that caused this harm. In itself, the fact of the infliction of damage does not indicate wrongfulness. In this case, the fault should not be defined as a fault in causing harm, but rather as the fault in carrying out a wrongful (unlawful) act. Within these relations there is a conflict between the legal presumptions concerning the legality and illegality of harming in private (civil) and public law. On this basis, the experts have concluded that in this case the fault and wrongfulness should not be considered from the standpoint of general tort. Furthermore, they find the current version of sections 1173-1176 of the Civil Code of Ukraine (hereinafter - CC of Ukraine) unsuccessful, since the application of the terms "illegal" and "regardless of fault" is acceptable only for the construction of general tort, under which the fault should be regarded as a fault in harm-doing, and illegality regarded as the wrongfulness of the harming. However, in this regard there is an opposite position in legal doctrine: when determining the illegality of harm caused by the state we should follow the general rule of general tort, that is, any infliction of damage by the authorities and their officials is wrongful, except as otherwise expressly provided

5 О.О. Отраднова, Недоговірні зобов'язання в иивільному праві України [Non-contractual obligations in civil law of Ukraine], Київ 2009, p. 73.

6 М.М. Хоменко, Особливості правового статусу держави як суб 'єкта иивільно-правової відповідальності у деліктних зобов'язаннях [Pесиliarities of the legal status of the state as a subject of civil liability in tortious obligations], “Адвокат" 2011, nо. 5(128), p. 31. 
by law. In other words, there should not be any exceptions to the general tort system for the obligations arising out of harm caused by the state. ${ }^{7}$

We agree with the position of the scholars who think that the liability for wrongfulness in the infliction of damage by public (including judicial) authorities should not be considered from the standpoint of general tort. In these cases, the "illegality" indicates the presence of fault. So position of the scholars who propose applying the concept of "wrongful" or even "unfair" instead of the concept of "illegal" is, in our view, quite reasonable. ${ }^{8}$ Therefore, in view of the provisions concerning the current legislation governing the legal sphere analysed in this paper, we will use the category of the "wrongfulness (unlawfulness)" of a court's decisions, acts and/or omissions. However, we believe that making changes to a number of legal acts governing relations on the compensation for damage caused by the judiciary, in replacement of the category of "illegal decisions, actions or omissions" in the category of "wrongful," would be a proper solution for the legislation of Ukraine.

It should be noted that in general, there are three forms of unlawful behavior as a result of which may be prejudiced: decision; action; inaction. ${ }^{9}$ Decisions and actions as a form of expression of unlawful behavior are usually the same, because they express a certain activity. The difference between them is that decision is the kind of action that is provided by the legal actors (for example, government authorities, their officials) and is subject to an appropriate external design, making them suitable for enforcement. In contrast, with actions the external expression of wrongful conduct is quite possible without special design. Wrongful action against rules of law or subjective protected by the legal rights of the others is a form of unlawful behavior. With this form of unlawful behavior, a person carries out precisely the action that should not have been taken. This action violates a duty established by a legal prohibition. ${ }^{10}$ That is why we consider it necessary to note that the possibility of expressing three forms of unlawful behavior, namely deci-

7 Н.А. Кирилова, Гражданско-правовая ответственность государства [Civil liability of the state], Москва 2003, p. 28.

8 С.В. Супрун, Возмещение материального ущерба, причинённого гражданам при раскрытии и расследовании преступлений: уголовно-прочессуальный и оперативно-розыскной аспекты [Compensation for pecuniary damage caused to the citizens in the course of detection and investigation of crimes: criminal procedure and operational search aspects], Омск 2001, p. 69; О.В. Михайленко, Имущественная ответственность за вред, причиненный осуществлением публичной власти: теоретические аспекты и проблемы ее реализации на практике [Property liability for harm caused by exercise of public authority: theoretical aspects and problems of its realization in practice], Москва 2007, p. 167.

9 А.Д. Прусаков, Действие и бездействие как формы юридически значимого поведения [Action and inaction as forms of legally significant behavior], Саратов 2008, p. 238.

10 М.К. Галянтич, А.Б. Гриняк, А.І. Дрішлюк, Т.С. Ківалова, Відшкодування моральної та матеріальної шкоди [Compensation for moral and material damage], Київ 2011, p. 58. 
sions, acts and omissions, are related to the obligation to compensate for damage caused by the judicial authorities.

Having analyzed the international and national levels of legal regulation pertaining to such relations, we can note the variety of legal systems' approaches concerning the definition and the list of unlawful decisions, acts or omissions of the judiciary, which may do harm to a person. The illegal activity or inactivity of the judiciary in criminal proceedings is characterized by the category "miscarriage of justice" (in the narrow sense $\mathrm{e}^{11}$ ) in the legislation of many countries. The same approach is used at the international (subsection 6 of section 14 of the International Covenant on Civil and Political Rights ${ }^{12}$ ) and regional levels of legal regulations pertaining to the obligation to compensate for the damage caused by the judicial authorities (Article 3 of Protocol no. 7 to the Convention on protection of human rights and fundamental freedoms, ${ }^{13}$ hereinafter - the ECHR). That is, a person's right to compensation for a miscarriage of justice in the exercise of criminal proceedings, such as an erroneous conviction, is envisaged. There are no normative definitions of a "miscarriage of justice" or specifying criteria for its concretization at the international and regional levels of legal regulation concerning compensation for damage caused by the judiciary. The opposite approach, namely the presence of legal definition or criteria specifying its content, can be observed at the level of national legal systems. ${ }^{14}$ In addition, the issue of the nature and meaning of "miscarriage of justice" has been considered in detail in foreign and domestic legal doctrine. However, one should note that the doctrinal definition and content of this category does not always coincide with its statutory understanding. Thus, some foreign scholars ${ }^{15}$ consider it necessary to interpret the category "miscarriage of justice" in several (or at least two) ways: narrowly (as noted above, refers to a miscarriage of justice in the exercise of criminal proceedings only) or broadly (a miscarriage of justice in the administration of justice, irrespective of the category of cases that may include not only the illegal final judgment, but also other illegal acts or omissions). As regards compensation for harm caused during the criminal

11 R. Iosof, Abstract of doctoral thesis "Civil liability of the state for miscarriages of justice", ClujNapoca, 2013, http://193.231.20.119/doctorat/teza/fisier/1171 [access: 28.03.2016].

12 International Covenant on Civil and Political Rights (adopted 16 December 1966, come into force 23 March 1976). GA res. 2200A (XXI), 21 UN GAOR Supp. (no. 16) at 52, UN Doc. A/6316 (1966); 999 UNTS 171; 6 ILM 368 (1967).

13 Convention for the Protection of Human Rights and Fundamental Freedoms. Protocol no. 7 (22 November 1984).

14 V., for instance, D. Layne, Compensation for Miscarriage of Justice, "Journal of Criminology" 2010, http://www.internetjournalofcriminology.com/Layne_Compensation_for_Miscarriage_ of_Justice.pdf [access: 28.03.2016].

15 R. Iosof, op. cit., pp. 16-17. 
proceedings, some scholars ${ }^{16}$ offer an alternative approach to focusing on the international and regional level for identifying forms of wrongful conduct by judicial authorities and their officials; namely, by formulating a list of wrongful (unlawful) decisions, acts and omissions that could cause harm to a person and take features of a criminal, disciplinary offense or a judicial error. In other words, in this case "miscarriage of justice" is not a generic term used to name other forms of wrongful behavior, but only one of the special terms used when denoting various forms of misconduct. In fact, a similar approach can be identified at the national level of regulating the analyzed sphere of legal relations.

In our opinion, based on an analysis of the international, regional and domestic levels of legal regulation pertaining to the compensation for damage caused by the judiciary, and doctrinal approaches to this issue, it is feasible to employ the following categories for different types of wrongful behavior: "unlawful decisions, acts or omissions," or "wrongful activity, inactivity," or "wrongful act in the form of an offense or objectively wrongful conduct," and so on. We believe that the category "miscarriage of justice," due to its content and scope, cannot be used as a generic term (that is, as an analogue of the category "unlawful behavior") for special terms (i.e. forms of wrongful behavior). Therefore we consider the implementation of the provisions of international instruments into national legislation inappropriate, given the state's obligation to comply with an adequate level of guarantees of rights and freedoms of person, to prevent the of narrowing of the content or scope of these rights and freedoms, and to ensure that effective mechanisms are in place to protect them in case of violation, non-recognition or challenge.

Thus, as has already been noted in this paper, the legislation of Ukraine describes the wrongful conduct of judicial officials as "illegal decisions, actions or inaction." This raises the issue of whether the statutory list of "illegal decisions, actions or omissions of the court" is exhaustive (closed). Based on a systematic interpretation of the provisions of section 1176 of CC of Ukraine ${ }^{17}$ (especially subsections 1 and 6 of this section) and section 1 of the Law of Ukraine On the Procedure of Compensation Damage Caused to a Citizen by Illegal Actions of Inquest, Pre-Trial Investigation, Office of Public Prosecu-

16 Л.А. Прокудина, Возмещение ущерба, причиненного гражданину незаконными действиями должностных лии в сфере уголовного судопроизводства [Compensation of damage caused to a citizen by illegal actions of officials in criminal proceedings], Москва 1987, p. 24; Н.В. Ильютченко, Возмещение ущерба, причиненного личности в уголовном процессе незаконными действиями органов дознания, предварительного следствия, прокуратуры и cyда [Compensation of damage caused to an individual in criminal proceedings by illegal actions of inquiry, preliminary investigation, prosecution and trial bodies (agencies)], Москва 1995, p. 20.

17 Цивільний кодекс України [Civil Code of Ukraine], 16.01.2003, no. 435-IV, із змінами і доповненнями; Відомості Верховної Ради України, 3.10.2003, nо. 40, item 356. 
tor and Judicial Bodies ${ }^{18}$ (hereinafter - the Law no. 266/94-VR), we can conclude that the list of different types of the judiciary and officials' illegal behavior that may harm a person is of inexhaustible (open) character. Moreover, the legislator pays particular attention to court decisions, acts or omissions, and wrongfulness (illegality) which leads to a significant restriction or violation of rights, freedoms and legitimate interests of persons, namely: unlawful conviction, ${ }^{19}$ unlawful criminal prosecution ${ }^{20}$ (under the Law no. 266/94-VR - unlawful notification of suspicion of a criminal offense ${ }^{21}$, unlawful use of preventive punishment, unlawful apprehension ${ }^{22}$ (under the Law no. 266/94-VR - illegal detention), and in accordance with the Law no. 266/94-VR: illegal conducting of search or capture caption, unlawful seizure of property, unlawful removal from work

18 Закон України Про порядок відшкодування шкоди, завданої громадянинові незаконними діями органів, що здійснюють оперативно-розшукову діяльність, органів досудового розслідування, прокуратури і суду, 1.12.1994, по. 266/94-ВР, із змінами і доповненнями, Відомості Верховної Ради України, 3.01.1995, nо. 1, item 2.1.

19 It is obvious that unlawful conviction is mentioned as first in the list of wrongful (illegal) acts of judiciary not without grounds, because it always leads to infliction of damage to person. The issues of the adequacy of the scope and composition, effectiveness of the procedure of compensation for such damage remain one of the most problematic and controversial both in domestic and in foreign doctrine and practice. V., for example: A. Bernhard, When Justice Fails: Indemnification for Unjust Conviction, "University of Chicago Roundtable" 1999, vol. 73, no. 6, http://ssrn.com/abstract=1316583 [access: 28.03.2016]; idem, Justice Still Fails: A Review of Recent Efforts to Compensate Individuals Who Have Been Unjustly Convicted and Later Exonerated, "Drake Law Review" 2004, vol.52, http://ssrn.com/abstract=1396849 [access: 28.03.2016]; H.-B. Schäfer, V. Fon, Incentive Effects of State Liability for Wrongful Conviction on the Level of Crime, Washington 2005, http://ssrn.com/abstract=999606 [access: 28.03.2016]; A.I. Kaplan, The Case for Comparative Fault in Compensating the Wrongfully Convicted, "UCLA Law Review" 2008, vol.56, no. 227, pp. 227-269 http://www.uclalawreview.org/pdf/56-1-6.pdf [access: 28.03.2016].

20 Attracting the criminal responsibility, as a stage of criminal prosecution, begins with bringing an accusation of commission of crime: п. 1.2. резолютивної частини рішення Конституційного Суду України у справі про депутатську недоторканність [р. 1.2. of ratio decidendi of the judgement of the Constitutional Court of Ukraine in the case of deputy immunity], 27.11.1999, по. 9, p. 99; Офіційний вісник України, 19.11.1999, nо. 44, item 71, 12591/1999. Attracting the criminal responsibility is a stage of criminal prosecution, that begins with notification of suspicion of a criminal offense: п. 14 ч. 1 ст. 3 чинного Кримінального процесуального кодексу (КПК) України [pars 14 of subsection 1 of section 3 of the effective Criminal Procedural Code (CPC) of Ukraine), 13.04.2012, no. 4651-VI, із змінами і доповненнями, Відомості Верховної Ради України, 8.03.2013, no. 9-10, item 474, 88.

21 Cf. главу 22 (pp. 276-279) КПК України [chapter 22 (sections 276-279) of CPC of Ukraine], 13.04.2012, по. 4651-VI, із змінами і доповненнями, Відомості Верховної Ради України, 8.03.2013, no. 9-10, item 474, 88.

22 There are such preventive punishments: personal obligation, personal surety, bail, house arrest, detention. Apprehension is a temporary preventive punishment. V. главу 18 КПК України [chapter 18 of CPC of Ukraine], 13.04.2012, no. 4651-VI, із змінами і доповненнями, Відомості Верховної Ради України, 8.03.2013, no. 9-10, item 474, 88. 
(position), and other procedural actions that limit the rights of citizens in the course of criminal proceedings, ${ }^{23}$ illegal use of simple detention ${ }^{24}$ or corrective labor, ${ }^{25}$ illegal forfeiture of estate, ${ }^{26}$ unlawful imposition of fine, ${ }^{27}$ illegal conducting of operative investigation activities, envisaged by the laws of Ukraine On Operative Investigation Activity, On Organizational Legal Principles of Struggle against the Organized Crime and other legislative acts, ${ }^{28}$ and execution of which entails the compensation in full for the harm caused, regardless of judicial official's fault.

However, in current legal research, scholars ${ }^{29}$ seek to extend the list of illegal actions of judicial bodies and their officials by setting additional conditions of objective (absolute, strict) state liability, such as: delayed admission of defense counsel, inhuman and cruel treatment during prosecution, ${ }^{30}$ violation of procedures for issuing perpetrators of criminal offenses (extradition ${ }^{31}$ ), all of which could be considered as a practice of

23 V. глави 10, 14-17, 20, p. 333 КПК України [chapters 10, 14-17, 20, section 333 of CPC of Ukraine], 13.04.2012, nо. 4651-VI, із змінами і доповненнями, Відомості Верховної Ради України, 8.03.2013, no. 9-10, item 474, 88.

24 V. ст. 32 Кодексу України про адміністративні правопорушення (КУпАП) [section 32 of Code of Ukraine on Administrative Infractions (CUAI)], 7.12.1984, no. 8073-X, із змінами і доповненнями, Відомості Верховної Ради УРСР, 18.12.1984, no. 51, item 1122.

25 V. ст. 31 КУпАП [section 31 of CUAI], 7.12.1984, nо. 8073-X, із змінами і доповненнями, Відомості Верховної Ради УРСР, 18.12.1984, no. 51, item 1122.

26 V. ст. 29 КУпАП [section 29 of CUAI], 7.12.1984, nо. 8073-X, із змінами і доповненнями, Відомості Верховної Ради УРСР, 18.12.1984, no. 51, item 1122; ст. 59 Кримінального кодексу (КК) України [section 59 of Criminal Code (CrC) of Ukraine], 5.04.2001, no. 2341-III, iз змінами і доповненнями, Відомості Верховної Ради України, 29.06.2001, no. 25, item 131.

27 V. ст. 27 КУпАП [section 27 of CUAI], 7.12.1984, nо. 8073-X, із змінами і доповненнями, Відомості Верховної Ради УРСР, 18.12.1984, no. 51, item 1122; ст. 53 КК України [section 53 of $\mathrm{CrC}$ of Ukraine], 5.04.2001, no. 2341-III, із змінами і доповненнями, Відомості Верховної Ради України, 29.06.2001, no. 25, item 131.

28 V. главу 21 КПК України [chapter 21 of CPC of Ukraine],13.04.2012, no. 4651-VI, із змінами і доповненнями, Відомості Верховної Ради України, 8.03.2013, nо. 9-10, item 474, 88.

29 V., for example: В. Буткевич, Якість закону і питання ефективності застосування рішень Європейського суду з прав людини судами Украйни (виступ на Міжнародній конферениіï) [Quality of law and the issue of effectiveness of application of the European Court of Human Right's judgements by courts of Ukraine (presentation at the International Conference)], “Право України” 2011, по. 7, pp. 48-63; В.П. Паліюк, Застосування Конвенщії про захист прав людини і основоположних свобод у випадку прогалин українського законодавства [Application of the Convention on protection of human rights and fundamental freedoms in the case of gaps in the Ukrainian legislation], [in] Актуальні проблеми формування громадянського суспільства та становлення правової держави, ред. II. Міжнар, Черкаси 2012, р. 378.

30 В.Ю. Горєлова, Відповідальність держави перед особою за завдання шкоди незаконними діями органів досудового розслідування, прокуратури і суду [State liability for the damage caused by illegal actions of pre-trial investigation, office of public prosecutor and judicial bodies], Київ 2012, p. 20.

31 В.П. Паліюк, Застосування судами загальної юрисдикції України Конвенщї про захист прав людини і основоположних свобод у разі «неякісного» законодавства (цивільно- 
the European Court of Human Rights (hereinafter - the ECHR) as a source of law in Ukraine. ${ }^{32}$ We support the position of these scholars and think that it would be suitable to expand the list of unlawful acts of judicial bodies and their officials, following the approaches of the ECHR.

Particular attention should be paid to the case of compensation for damage caused to an individual or legal entity as the result of a court rendering an illegal decision in a civil case (subsection 5 of section 1176 of CC of Ukraine). Based on the literal wording of the text of the analyzed provision of CC of Ukraine, we can conclude that it only concerns compensation for damage caused as a result of rendering an illegal decision in a civil case. That is, when the illegal decision has been delivered on an administrative or commercial matter, compensation for damage under subsection 5 of section 1176 of CC of Ukraine is impossible. Obviously, in this case, we should apply the provisions of subsection 6 of section 1176 of CC of Ukraine, with the possibility of compensation for damage on the general terms established by sections 1173, 1174 of CC of Ukraine. This raises the issue of the feasibility and effectiveness of such an approach to the legal regulation of analyzed relations, because actually the legislator establishes different modes of regulation for identical (same type) relations, since, in contrast to subsection 5 of section 1176 of CC of Ukraine, under sections 1173, 1174 of CC of Ukraine, damage is compensated for regardless of the fault of the public authority or official. We believe that there are no convincing arguments in support of, or rationale for, this legislative approach, so there are substantial doubts concerning its further preservation.

In this regard, it is necessary to amend subsection 5 of section 1176 of CC of Ukraine, as follows ${ }^{33}$ :

The damage caused to an individual or legal entity as a result of the court rendering a wrongful (illegal) decision ${ }^{34}$ in a civil, commercial or administrative case shall

правовий аспект) [Application of the Convention on protection of human rights and fundamental freedoms by courts of general jurisdiction of Ukraine in the case of "poor" legislation (civil legal aspect)], "Часопис цивільного і кримінального судочинства" 2013, по. 5(14), pp. 105-106; also Dubovik v. Ukraine, no. 33210/07, 41866/08, § 71-75, ECHR 2009; Kaboulov v. Ukraine, no. 41015/04, § 155, 159, ECHR 2009.

32 Ст. 17 ЗУ Про виконання рішень та застосування практики Європейського суду з прав людини [section 17 of the Law of Ukraine On the Fulfillment of Decisions and Application of Practice of the European Court of Human Rights], 23.02.2006, no. 3477-IV, із змінами та доповненнями, Відомості Верховної Ради України, 28.07.2006, no. 30, item 1114, 260.

33 Similar proposals have been already expressed in the legal literature. Cf. О.О. Боярський, Відшкодування шкоди, завданої незаконними ріменнями, діями чи бездіяльністю суду [Сотpensation of damage caused by illegal decisions, actions or omissions of court], Одеса 2008, pp. 11, 86.

34 We believe that it is appropriate to use the term "judicial decision" (similar to the subsection 3 of section 61 of the Civil Procedural Code of Ukraine: judicial decision in civil, commercial or administrative case...) because, in accordance with the current procedural law of Ukraine (subsection 1 of section 95, subsection 1 of section 208 of the Civil Procedural Code, sections 
be fully compensated by the state, in the case of finding that judge's acts led to the delivery of the wrongful (illegal) decision by a court's conviction, that has come into force.

It should be noted that the proposed legislative change corresponds to the current procedure of compensation for damage caused by the judiciary. That is why, taking into account the procedure of compensation for such damage proposed in this author's recent publication, ${ }^{35}$ the above-mentioned wording of subsection 5 of section 1176 of CC of Ukraine will require additional changes to determine the source of the compensation:

The damage caused to an individual or legal entity as a result of the court rendering a wrongful (illegal) decision in an civil, commercial or administrative case shall be fully compensated from the special accumulative account of the individual judge for funds with the intended purpose, in the case of finding that judge's acts led to the delivery of the wrongful (illegal) decision by a court's conviction, that has come into force, and proportionally, as determined by the court, or in the case of the failure of such a determination - jointly and severally. ${ }^{36}$ If there are insufficient funds in the judge's accounts, the sums due as compensation are paid by the state.

It should be noted that some scholars ${ }^{37}$ consider the rule of damage compensation only in case when the judge's guilt is specified in the court's sentence, as an arbitrary

4-5 of Commercial and Procedural Code, subsections 12, 13 of section 3, section 158 of the Code of Administrative Proceedings), the judgment is only one of the forms (correctly - a type of) judicial decisions.

35 С.В. Куліцька, Проблемні питання порядку відшкодування (компенсаиіі) шкоди, заподіяної неправомірними (незаконними) ріменнями, діями чи бездіяльністю суду (судді, cyддів) [The issues of procedure of compensation of damage caused by court's (judge's) wrongful (unlawful) decisions, acts or omissions], "Науковий вісник Ужгородського національного університету,” Серія “Право," Випуск 35, Ч. 1, Т. I, 2015, pp. 142-143.

36 V. ч. 1 ст. 1190 ЦК України [subsection 1 of section 1190 of CC of Ukraine] and абз. 2 п. 3 постанови Пленуму Верховного Суду України "ро практику розгляду судами цивільних справ за позовами про відшкодування шкоди”, 27.03.1992, nо. 6 [§ 3 of the resolution of the Plenum of the Supreme Court of Ukraine "On the practice of judicial consideration of civil cases for damages"], http://zakon4.rada.gov.ua/laws/show/v0006700-92 [access: 28.03.2016]: persons who jointly caused damage that is caused indivisible damage by interrelated, cumulative actions or by actions of the same purposes, are jointly and severally liable before the injured persons.

37 И.А. Тактаев, Ответственность публично-правовых образований за вред, причиненный их органам и должностным лииам [Liability of public law entities for damage caused by their bodies and officials], Москва 2003, pp. 9-10; А.Э. Колиева, Ответственность за вред, причиненный актами правоохранительных органов и суда: гражданско-правовой асneкm [Liability for damage caused by acts of law enforcement agencies and courts: civil legal aspect], Краснодар 2007, pр. 7-8, 17; М.М. Хоменко, Відшкодування шкоди, завданої органами 
limitation of the responsibility of the state, which violates the constitutional rights of access to justice and compensation of damage. Limitations of compensation duty can be either substantive, relating to the conditions of compensation, or procedural, directly related to the procedure of compensation. Obviously, the rule of subsection 5 of section 1176 of CC of Ukraine envisages both types of limitations. The substantive aspect is to change the presumptions: from the civil presumption of the wrongdoer's guilt (subsection 2 of section 1166 of CC of Ukraine) to the criminal presumption of innocence (subsection 2 of section 2 of the Criminal Code of Ukraine). In addition, there is a paradoxical situation: the possibility of the liability of the actor (the state) is made dependent on whether one of the bodies of this actor will be able to prove the guilt of another of his body. At the same time, a wronged person has limited opportunities to prove one of the conditions of liability - guilt. Therefore scholars propose establishing a broader liability for damage caused in the course of justice, noting that for the purpose of revision of judgments and of liability for damage resulting from the exercise of judicial power, it is necessary to establish the following statutory rules: compulsory previous recognition of the judicial act which caused damage to the person as wrongful (illegal); and prior use of all possible legal remedies to review and appeal against the judicial act which caused damage. We consider the position of these scholars one that deserves attention, because it is also confirmed by the approaches of national jurisprudence. Thus, the Higher Administrative Court of Ukraine in its ruling from May, 10, 2006 pointed out that the courts could only appeal acts, actions or omissions of the judicial officials, if those acts, actions or omissions belonged to the managerial rather than procedural activity of the judge. An appeal against the procedural activity of the judge in the course of justice cannot be made by submission of the civil claim. ${ }^{38}$ In accordance with the resolution of the Plenum of the Supreme Court of Ukraine from June, 12, 2009 no. 6: On some issues arising in the judicial practice in taking proceedings before administrative courts and their consideration of administrative lawsuits against the courts and judges ${ }^{39}$ it is clarified that in understanding the provisions of subsection 1 of section $2, \S \S 1$,

державної влади, їх посадовими та (або) службовими особами [Cотреnsation of damage caused by public authorities and their officials], Київ 2012, p. 142.

38 Ухвала Вищого адміністративного суду України, 10.05.2006 [Ruling of the Higher Administrative Court of Ukraine] http://zakon4.rada.gov.ua/laws/show/n0030760-06 [access: 28.03.2016].

39 Постанова Пленуму Верховного Суду України “Про деякі питання, що виникають у судовій практиці при прийнятті до провадження адміністративних судів та розгляді ними адміністративних позовів до судів і суддів," 12.06.2009, no. 6 [Resolution of the Plenum of the Supreme Court of Ukraine On some issues arising in the judicial practice in taking proceedings before administrative courts and their consideration of administrative lawsuits against the courts and judges], http://zakon4.rada.gov.ua/laws/show/v0006700-09 [access: 28.03.2016]. 
7, 9 of section 3, section 17, subsection 3 of section 50 of the Code of Administrative Proceedings of Ukraine, courts and judges in their consideration of civil, commercial, criminal, administrative cases and cases of administrative offenses are not actors vested with authoritative powers, performing powerful managerial functions, and cannot be defendants in cases of appeal against their decisions, actions or omissions committed in connection with the litigation. According to the position of the civil cases chamber of the Higher specialized court of Ukraine for consideration of civil and criminal cases, ${ }^{40}$ the aforementioned explanations of the Supreme Court of Ukraine correspond to the provisions of Articles 62,126 and 129 of the Constitution of Ukraine, which stipulates that a judgement and the acts or omissions of the courts connected with it in matters of justice related to the preparation, consideration of cases in courts, etc., may be appealed in accordance with the procedural laws, not by appealing their actions to another court, as this violates the principle of judicial independence and the prohibition of interference with the settlement of the case by the proper court. In this connection the rules of the Civil Procedural Code of Ukraine (hereinafter - CPC of Ukraine) or other laws of Ukraine do not provide the court examination of the plaintiff's counts, regardless of their presentation and purport, the subject-matter of which, in fact, is, an appeal against the procedural activity of the court (judge), related to the proceedings. Thus, in this case the opening of the proceedings should be refused under $\S 1$ of subsection 2 of section 122 of CPC of Ukraine, and in the event that the proceedings are opened they should be closed under $\S 1$ of subsection 1 of section 205 of CPC of Ukraine.

Therefore, in our opinion, the establishment of a uniform rule on state responsibility for any wrongful (illegal) decisions, actions or omissions of the judiciary or their officials - which resulted in damage to the rights, freedoms or legally protected interests of a person, regardless of whether the damage was caused in the course of justice or due to other procedural activity, and regardless of whether there was a court sentence which established the judge's guilt — is one of the key directions for future legal reform in Ukraine. Such an approach to the legal regulation of the analyzed relations will correspond with the international standards of judicial independence and facilitate the formation of an effective means of protection of a person's right to compensation for damage caused by the judicial authority and provide additional guarantees of the realization of this right in Ukraine. Furthermore, we believe that the procedure of compensation for damage that was analyzed in detail in the author's aforementioned publication, and the legislative changes and amendments proposed in this paper, should be introduced in Ukraine.

40 Інформаційний лист судової палати у цивільних справах Вищого спеціалізованого суду України з розгляду цивільних і кримінальних справ по. 6-182/0/4-12, 13.02.2012 [Information letter of the civil cases chamber of the Higher specialized court of Ukraine for consideration of civil and criminal cases], http://zakon2.rada.gov.ua/laws/show/v-182740-12 [access: 28.03.2016]. 
The wrongfulness of liabilities for the infliction of damage by judicial authorities takes on a special character and specific content, so it should not be considered from the standpoint of general tort. In connection with this, making changes to a number of legal acts governing relations on compensation for damage caused by the judiciary, to replace the category of "illegal decisions, actions or omissions" in the category of "wrongful (unlawful)," might be proper or the legislation of Ukraine.

Three forms of unlawful behavior: namely decisions, acts and omissions, are related to the obligations of compensation for damage caused by the judicial authorities. Analysis of the international, foreign and national levels of legal regulation of the studied relations illustrates the variety of the legal system's approaches concerning the definition and the list of unlawful decisions, acts or omissions of the judiciary, which may do harm to a person. The category "miscarriage of justice" is used as a generic term for the aforementioned forms of wrongful behavior under the provisions of some international instruments and legislation of some foreign countries. In our opinion, usage of the categories "unlawful decisions, acts or omissions" or "wrongful activity, inactivity" or "wrongful act in the form of an offense or objectively wrongful conduct" and so on, is appropriate for different types of wrongful behavior.

The problem of extending the list of wrongful actions of judicial bodies and their officials is particularly relevant for Ukraine, considering the practice of the European Court of Human Rights.

Particular attention should be paid to the case of compensation for damage caused to an individual or legal entity as a result of a court rendering an illegal decision in a civil case (subsection 5 of section 1176 of $\mathrm{CC}$ of Ukraine). We believe that it is necessary to amend subsection 5 of section 1176 of CC of Ukraine, as follows:

The damage caused to an individual or legal entity as a result of a court rendering a wrongful (illegal) decision in a civil, commercial or administrative case shall be fully compensated from the special accumulative account of the individual judge from funds with the intended purpose, in the event of finding the corpus of criminal offense in the judge's acts that affected the delivery of the wrongful (illegal) decision by a court's conviction, that has come into force. The damage caused to an individual or legal entity as a result of a panel of judges acting as a court rendering a wrongful (illegal) decision in civil, commercial or administrative case shall be fully compensated from the special accumulative account of the particular judges, who have comprised the panel, from funds with the intended purpose, in the case of corpus of criminal offense in judge's acts that affected the delivery of the wrongful (illegal) decision by a court's conviction, that has come into force, and proportionally, as determined by the court, or in the case of failure of such determination - jointly and 
severally. If there are insufficient funds in a judge's accounts, sums due for compensation are paid by the state.

\section{Literature}

Басін К.В., Юридична відповідальність: природа, форми реалізаиї та права людини [Legal liability: the nature, forms of implementation and human rights], Київ 2006. Базылев Б.Т., Юридическая ответственность (теоретические вопросы) [ Legal liability (theoretical issues)], Красноярск 1985.

Боярський О.О., Відшкодування шкоди, завданої незаконними рішеннями, діями чи бездіяльністю суду [Compensation of damage caused by illegal decisions, actions or omissions of court], Одеса 2008.

Буткевич В., Якість закону і питання ефективності застосування рішень Свропейського суду з прав людини судами України (виступ на Міжнародній конферениіi) [Quality of law and the issue of effectiveness of application of the European Court of Human Right's judgements by courts of Ukraine (presentation at the International Conference)], “Право України” 2011, по. 7.

Галянтич М.К., Гриняк А.Б., Дрішлюк А.І., Ківалова Т.С. та ін., Відшкодування моральної та матеріальної шкоди, ред. М.К. Галянтич [Compensation for moral and material damage], Київ 2011.

Горєлова В.Ю., Відповідальність держави перед особою за завдання шкоди незаконними діями органів досудового розслідування, прокуратури $і$ суду [State liability for the damage caused by illegal actions of pre-trial investigation, office of public prosecutor and judicial bodies], Київ 2012.

Ильютченко Н.В., Возмещение ущчерба, причиненного личности в уголовном проиессе незаконньлми действиями органов дознания, предварительного следствия, прокуратуры и суда [Compensation of damage caused to an individual in criminal proceedings by illegal actions of inquiry, preliminary investigation, prosecution and trial bodies (agencies)], Москва 1995.

Канзафарова И.С., Гражданско-правовая ответственность (основные положения) [Civil liability (the main provisions)], Одесса 1998.

Кирилова Н.А., Гражданско-правовая ответственность государства [Civil liability of the state], Москва 2003.

Колиева А.Э., Ответственность за вред, причиненньй актами правоохранительных органов и суда: гражданско-правовой аспект [Liability for damage caused by acts of law enforcement agencies and courts: civil legal aspect], Краснодар 2007.

Коновалов С.А., Основание гражданско-правовой ответственности [The ground of civil liability], Москва 2006. 
170 | Adam Mickiewicz University Law Review

Куліцька С.В., Проблемні питання порядку відшкодування (компенсаиії) шкоди, заподіяної неправомірними (незаконними) ріменнями, діями чи бездіяльністю суду (суддi, суддів) [The issues of procedure of compensation of damage caused by court's (judge's) wrongful (unlawful) decisions, acts or omissions], "Науковий вісник Ужгородського національного університету," Серія “Право," Випуск 35, Ч. 1, Т. I, 2015.

Михайленко О.В., Имущественная ответственность за вред, причиненный осуществлением публичной власти: теоретические аспекты и проблемы ее реализации на практике [Property liability for harm caused by exercise of public authority: theoretical aspects and problems of its realization in practice], Москва 2007.

Отраднова О.О., Недоговірні зобов'язання в иивільному праві Украӥни [Non-contractual obligations in civil law of Ukraine], Київ 2009.

Паліюк В.П., Застосування судами загальної юрисдикиї Украӥни Конвениії про захист прав людини і основоположних свобод у разі «неякісного» законодавства (иивільно-правовий аспект) [Application of the Convention on protection of human rights and fundamental freedoms by courts of general jurisdiction of Ukraine in the case of "poor" legislation (civil legal aspect)], “Часопис цивільного і кримінального судочинства" 2013, по. 5(14).

Паліюк В.П., Застосування Конвениії про захист прав людини і основоположних свобод у випадку прогалин українського законодавства [Application of the Convention on protection of human rights and fundamental freedoms in the case of gaps in the Ukrainian legislation], Актуальні проблеми формування громадянського суспільства та становлення правової держави: зб. наук. пр. II-ї Міжнар. наук.практ. конф., Черкаси 2012.

Прокудина Л.А., Возмещчение ущзерба, причиненного гражданину незаконными действиями должностньх лии в сфере уголовного судопроизводства [Cотрепsation of damage caused to a citizen by illegal actions of officials in criminal proceedings], Москва 1987.

Прусаков А.Д., Действие и бездействие как формы юридически значимого поведения [Action and inaction as forms of legally significant behavior], Саратов 2008.

Савицька А.М., Поняття протиправності та ї̈ форми за радянським ичвільним правом [The concept of wrongfulness and its forms under the Soviet civil law], Львів 1974.

Слесарев В.Л., Объект и результат гражданского правонарушения [The object and the result of a civil offence], Свердловск 1974.

Супрун С.В., Возмещение материального ущеерба, причинённого гражданам при раскрытии и расследовании преступлений: уголовно-прочессуальный и оперативно-розыскной аспекть [Compensation for pecuniary damage caused to the citizens in the course of detection and investigation of crimes: criminal procedure and operational search aspects], Омск 2001. 
Тактаев И.А., Ответственность публично-правовых образований за вред, причиненныий их органам и должностным лищам [Liability of public law entities for damage caused by their bodies and officials], Москва 2003.

Халфина Р.О., Общее учение о правоотношении [General theory of legal relationship], Москва 1974.

Хоменко М.М., Відшкодування шкоди, завданої органами державної влади, їх посадовими та (або) службовими особами [Compensation of damage caused by public authorities and their officials], Київ 2012.

Хоменко М.М., Особливості правового статусу держави як суб'єкта ичивільноправової відповідальності у деліктних зобов'язаннях [Peculiarities of the legal status of the state as a subject of civil liability in tortious obligations], “Адвокат” 2011, no. 5(128).

\section{SUMMARY \\ Wrongfulness of a court's decisions, acts and/or omissions as a condition of tortious obligations in Ukraine}

An attempt to analyze one of the necessary conditions determining the obligations to compensate for damage caused by the judiciary is made in the article. The author focuses on the wrongfulness of a court's decisions, acts and/or omissions as a condition of such obligations. It is emphasized that the category "miscarriage of justice" is used as a generic term for the aforementioned forms of wrongful behavior under the provisions of some international instruments and the legislation of some foreign countries. Meanwhile, the author shows that the incorporation of such an approach into national legislation is inappropriate. It is concluded that the problem of extending the list of wrongful actions of judicial bodies and their officials is particularly relevant for Ukraine, considering the practice of the ECHR. Special attention is given to the case of compensation for damage caused to an individual or legal entity as a result of a court rendering an illegal decision in a civil case.

Keywords: wrongfulness, unlawfulness, court's decisions, acts, omissions, compensation of damage, tortious obligations

Sofiya V. Kulitska, Faculty of Law, Taras Shevchenko National University of Kyiv, Volodymyrska 60, Kiev 01033, Ukraine, e-mail: svkulitska@gmail.com. 